\title{
Developing a Prototype of Early Warning System of Delay Risks for Public Projects (EWaSDRiP)
}

\author{
Jati Utomo Dwi Hatmoko ${ }^{1, *}$, Hery Priyono ${ }^{1}$, Mochamad Agung Wibowo ${ }^{1}$, and Riqi Radian \\ Khasani $^{1}$ \\ ${ }^{1}$ Civil Engineering Department, Diponegoro University, Semarang - Indonesia
}

\begin{abstract}
Delays may occur during pre-construction or construction phases, or both. The aim of this research is to develop a prototype of an early warning system of delay risks for public projects in pre-construction phase (EWaSDRiP). These delays are attributed to owner, consultant, project characteristics, and external factors. Data was collected through literature review, observations on project reports, interview, and questionnaire surveys with 30 respondents from government client teams, contractors and consultants. The respondents were asked to validate the indicators, and estimate their weight and the degree of accuracy. A 1 to 10 Likert scale reflecting worst to excellent is used to score the state of each of the delay indicators within three zones, i.e. red (scale 1-3), yellow (4-6), green (7-10). The delays in red zone indicates that they pose dangerous threats to the project and must be monitored closely, delays within yellow zone indicate moderate threats to the project, while delays in green zone means that they are unlikely to delay the project. EWaSDRiP gives a visual indication of which zone most delays are distributed. This prototype is potentially beneficial for the owner or government client team to prepare strategic actions for the relevant pre-construction delays accordingly.
\end{abstract}

\section{Introduction}

Delays have long been recognised as one of main problems in public construction projects. Their impacts, financially and socially, are significant to project stakeholders as well as to society. Quite often delays prevent the owner or users to take benefits of the project as scheduled.

Delays may occur during pre-construction or construction phases, or both. While many literature are mainly focused on delays during construction phase (e.g. [1-4]), delays occurring in pre-construction phase may also impact quite significantly on the project completion time [5,6]. Delays due to problems in public project procurement, for example, may prevent the project to start on schedule, resulting in late project completion. It is also very common that the late start of a project may put the winning contractors in difficult situation due to unrealistic remaining project durations. On the other side, it is not

* Corresponding author: jati.hatmoko@ft.undip.ac.id 
uncommon that project owners (government clients) have no comprehensive understanding at early stage on whether or not the projects of which they are responsible will be completed meeting the target date. Therefore, an instrument to assess and predict prior to project execution is required [7-9]. Besides predicting the project final status based on conditions in pre-construction phase, this tool will also be beneficial to give confidence to the government client team about the project. The aim of this research is to develop a prototype of an early warning system of delay risks for public projects in pre-construction phase (EWaSDRiP).

\section{Delay risks in Public projects}

A study of delay risks in public project found the top three delay factors, i.e. delays related to information delivery and exchange between related parties, lack of competencies of owner, and lack of capabilities of supervision consultant [10]. Koushki et.al [11] highlighted three main causes of delays by project owners, i.e. changes to orders, financial constraints and lack of experience of owners in the construction business. Chabota et.al [12] found that delayed payments were the main causes of the project delays, followed by financial processes, financial difficulties, economic problems, contract modifications, material procurement, personnel issues, changes in drawings, equipment inadequacy, lack of supervision, construction errors, poor coordination on site, changes in specifications and labor disputes and strikes. This result is similar with the finding of Aibinu and Odeyenka [13] who found the contractor's financial factor as one of the main causes of delays among 44 delay factors identified from construction manager perspective. While Messah et.al [14] found main factors causing delays during construction phase of building projects as agreed by contractors, owners, and supervisor consultants, i.e. lack of manpower, unavailability or late delivery of materials, unavailability of construction equipment, and non-contract payments.

Table 1. Selection of project delay risks in pre-construction phase

\begin{tabular}{|l|l|}
\hline \multicolumn{1}{|c|}{ Delay Risks } & \multicolumn{1}{c|}{ Reference } \\
\hline Owner & \\
\hline Imbalanced ratio of project supervisor and number of project supervised & {$[13,15,16,32]$} \\
\hline Late project procurement & {$[16,17,18,31,32]$} \\
\hline Late budget of project agreed & {$[15,16,19,31,32]$} \\
\hline Technical specification incomplete & {$[11,14,16,29,32]$} \\
\hline Incompetence of head of project & {$[2,16,20,32]$} \\
\hline Consultant & \\
\hline Incompetence of consultant & {$[10,15,28,29,32]$} \\
\hline Late drawing approval & {$[11,15,16,29,31]$} \\
\hline Design errors & {$[16,21,22,29,31]$} \\
\hline Incomplete design drawing & {$[14,15,16,29,31]$} \\
\hline Poor quality of supervision & {$[14,15,28,29,32]$} \\
\hline Project Characteristic & \\
\hline Project scale & {$[15,16,28,30,32]$} \\
\hline Complex project & {$[15,16,19,32]$} \\
\hline Unrealistic project duration & {$[15,16,19,29,31]$} \\
\hline Contract is signed late & {$[14,15,28,31,32]$} \\
\hline Remote project location & {$[15,28,29,30,32]$} \\
\hline Site not ready & {$[15,23,28,29,31]$} \\
\hline External factors & \\
\hline Unavailability of certain materials in the market & {$[15,16,19,29,31]$} \\
\hline Inclement weather condition & {$[15,16,28,29,31]$} \\
\hline Uncertainty due to new regulation related to project & {$[14,15,16,29,31]$} \\
\hline
\end{tabular}


From various studies of delay risks mentioned earlier, it can be concluded that delays risks can be originated from owner, contractor, consultant, project characteristics, and external factors. Table 1 shows the results of identified delay risks in pre-construction phase, which later are used as indicators of EWaSDRiP.

\section{Early warning system and use of EWaSDRiP}

In general, an early warning system is designed to alert the occurrence of undesirable events to minimize the incidents, such as natural disasters, political chaos, wars, accidents, and delays $[24,25]$. Early warning systems can be applied in risk assessment, safety risk, mitigation delay, project performance and problem solving on construction projects (e.g. $[26,27])$.

EWaSDRiP is intended to be used during pre-construction phase by particularly project owner (Fig 1). The use of this instrument prior to the construction phase will allow the project owner to predict the final status of the project earlier based on the condition and information available during pre-construction phase.

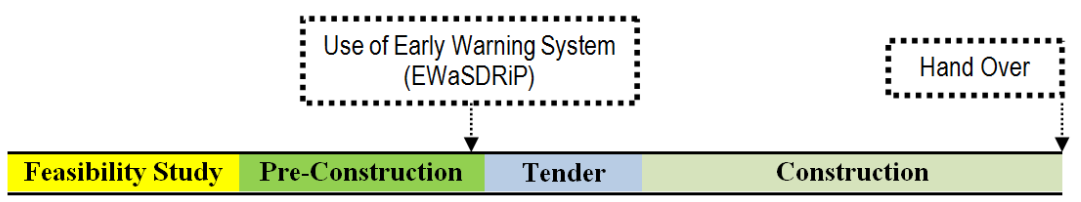

Fig. 1. Use of Early Warning System (EWaSDRiP) in a project timeline

\section{Research method}

Data of project delays was collected through literature review, observations on project reports, interview, and questionnaire surveys with 30 respondents, which consists of government client teams (20\%), contractors (33\%), and consultants (47\%). Most of respondents $(>54 \%)$ have more than ten years of experience. Collections of delays identified were classified based on when they might occur, i.e. pre-construction and construction phases, and only delays in pre-construction phase were then used as indicators for the instrument. These delays were later attributed to owner, consultant, project characteristics, and external factors. The respondents were asked to validate the indicators obtained from literature review, and estimate the weight of each indicator based on the impact to the project completion, and the state the degree of accuracy of each indicator. This degree of accuracy indicates the extent of accurateness of each indicator in predicting delay risks which can occur during construction phase.

\section{Results}

Table 2 shows the instrument of EWaSDRiP. A 1 to 10 Likert scale reflecting worst to excellent is used to score the state of each of the delay indicators within three zones, i.e. red (scale 1-3), yellow (4-6) and green (7-10) (see Table 1). Any potential delays with scores fall into red zone simply mean that they pose dangerous threats to the project and must be watched closely. Potential delays within yellow zone indicate moderate threats to the project, while the state of potential delays in green zone means that they are unlikely to delay the project. When the score of each delay is plotted on Table 1, it gives a visual indication of which zone most delays are distributed. To calculate the total impact of each 
delay to the project (T), the score (S) is multiplied by the weight (W) and accuracy (A). The cumulative total $(\mathrm{CT})$ of the total impact $(\mathrm{T})$ basically represents the prediction of the state of project completion, which can be classified into three categories, i.e. high possibility to be delayed $(0<\mathrm{CT}<4)$, moderate possibility to be delayed $(4 \leq \mathrm{CT}<7)$, low possibility to be delayed $(7 \leq \mathrm{CT}<10)$.

Table 2. The prototype of early warning system of delay risks for public projects (EWaSDRiP)

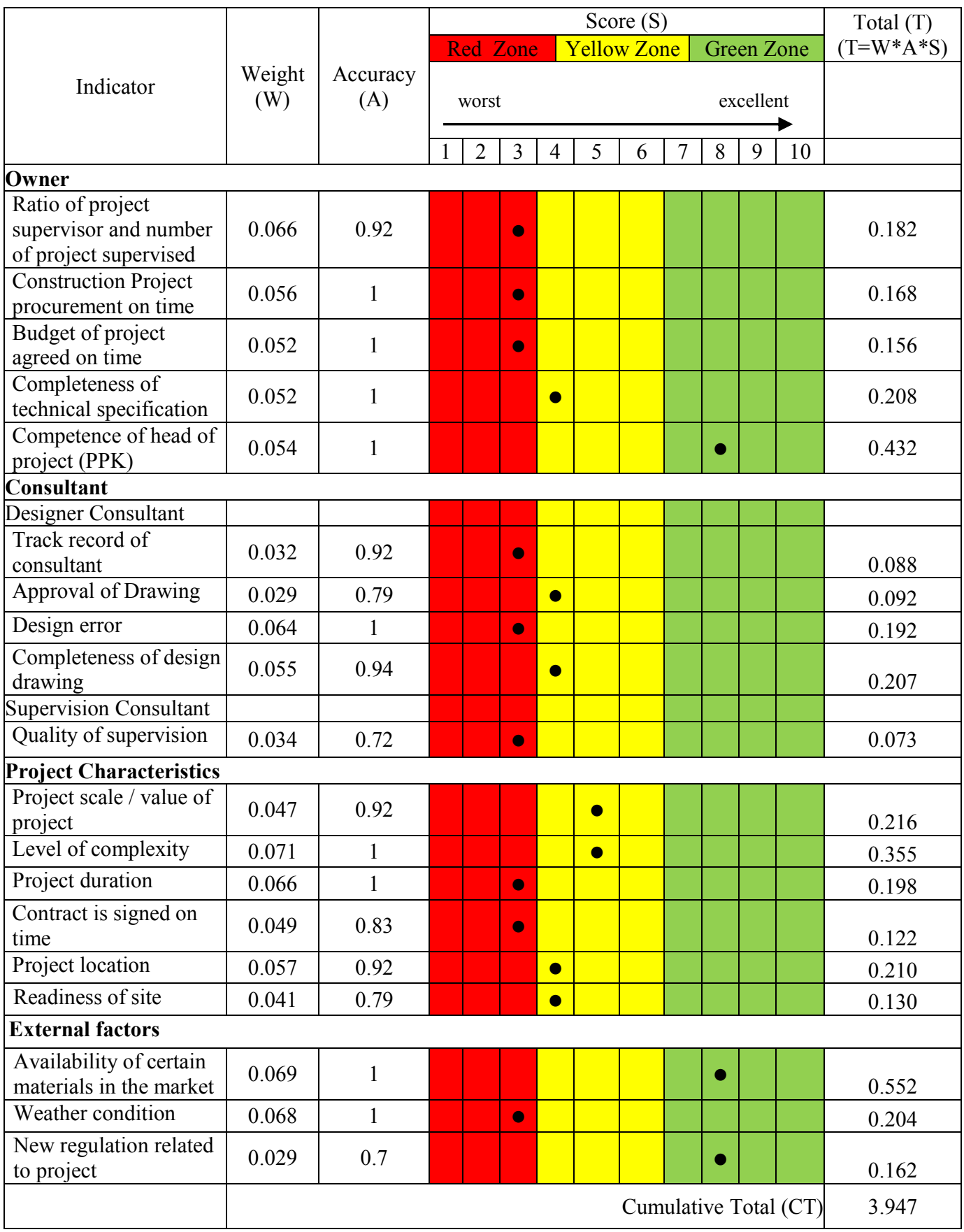




\section{Simulating EWaSDRiP}

To give a clearer picture of how EWaSDRiP works, a simulation has been done by assuming a hypothetical 4-storey building project to be observed (see Table 1). The project was assumed to be late in the procurement process, due to long process of budget agreement with the legislative. The contract was finally signed in late August, practically leaving less than four months for the contractor to finish the project. The design was regular, with materials locally available. The head of project was a civil servant with civil engineering background and 20 years of experience, however due to recent job rotation, he was lacking of staffs to supervise this project. The project was located at rather remote area. Since the project started in September, lots of rain was expected during the construction. The design drawing had many errors and was often incomplete. The supervision consultant had bad reputation for its quality supervision.

Based on the description, the project is then assessed using EWaSDRiP, resulting a cumulative total $(\mathrm{CT})$ equals to 3.947 , which falls into the red zone $(0<\mathrm{CT}<4)$. This means that this project has high possibility to be delayed, and must be monitored extensively. The distribution of black dots in the instrument representing scores of indicators, and visually helps the owner to recognise indicators which must be monitored closely to avoid delays. This simulation proves that EWaSDRiP does work and is useful for project owner to find delay risks early, and to predict the final status of the project completion, so that immediate actions can be taken.

\section{Conclusions}

This research has proposed a prototype of an early warning system of delay risks for public construction projects. This prototype is the first of its kind which is expected to give a significant contribution in tackling acute problems of delays in public projects in Indonesia. This instrument is beneficial for the owner or government client team to prepare strategic actions for the relevant pre-construction delays accordingly. Further research will be carried out by implementing it to public projects as case studies and to evaluate the applicability as well as the accuracy of the instrument.

\section{References}

1. J. U. D. Hatmoko and S. Scott, Constr. Manag. Econ.28,1 (2010)

2. J. U. D. Hatmoko and R. R. Khasania, Civ. Eng. Dimens. 18,2 (2016)

3. J. K. Larsen, G. Q. Shen, S. M. Lindhard, and T. D. Brunoe, J. Manag. Eng. 32 (2015)

4. O. Bagaya and J. Song, J. Manag. Eng. 32 (2016)

5. T. Ophiyandri, D. Amaratunga, C. Pathirage, and K. Keraminiyage, Int. J. Disaster Resil. Built Environ. 4 (2013)

6. H. Samarghandi, S. M. M. Tabatabaei, P. Taabayan, A. M. Hashemi, and K. Willoughby, J. Constr. Dev. Ctries. 21,1 (2016)

7. W. He, Y. Duan, L. Deng, and W. Zhou, J. Perform. Constr. Facil. 30,1 (2016)

8. L. Y. Ding et al., Autom. Constr.36 (2013)

9. Z. Yuan, Y. Wang, and C. Sun, J. Intell. Fuzzy Syst. 32, 1 (2017)

10. L. T. Van, N. M. Sang, and N. T. Viet, ARPN J. Sci. Technol. 5, 2 (2015) 
11. P. A. Koushki, K. Al-Rashid, and N. Kartam, Constr. Manag. Econ. 23, 3 (2005).

12. C. Kaliba, M. Muya, and K. Mumba, "Cost escalation and schedule delays in road construction projects in Zambia," Int. J. Proj. Manag. 27, 5 (2009).

13. A. A. Aibinu and H. A. Odeyinka, 132, 7 (2006)

14. Y. A. Messah, T. Widodo, and M. L. Adoe, J. Tek. Sipil 2, 2 (2013)

15. R. F. Aziz and A. A. Abdel-Hakam, Alexandria Eng. J. 55, 2 (2016)

16. J. Mccord, M. Mccord, P. T. Davis, M. Haran, and W. J. Rodgers, J. Financ. Manag. Prop. Constr. Iss Int. J. Manag. Proj. Bus. 20,1 (2015)

17. A. M. Odeh and H. T. Battaineh, Int. J. Proj. Manag. 20, 1 (2001)

18. Y. Frimpong, J. Oluwoye, and L. Crawford, Int. J. Proj. Manag. 21, 5 (2003)

19. A. Adam, P.-E. B. Josephson, and G. Lindahl, Eng. Constr. Archit. Manag. 24, 3 (2017)

20. B. Mpofu, E. G. Ochieng, C. Moobela, and A. Pretorius, Eng. Constr. Archit. Manag. 24, 2 (2017)

21. M. Sambasivan and Y. W. Soon, Int. J. Proj. Manag. 25, 5 (2007)

22. S. A. H. Tumi, A. Omran, and A. H. K. Pakir, The International Conference on Economics and Administration, 265-272 (2009)

23. J. U. D. Hatmoko and R. R. Khasani, Applied Mechanics and Materials, 845 (2016)

24. a Mert, M. Erd, and Y. Fahjan, Bull. Earthq. Eng. 1, 272 (2004)

25. Z. Yuan, Y. Wang, and C. Sun, J. Intell. Fuzzy Syst. 32, 1 (2017)

26. W. He, Y. Duan, L. Deng, and W. Zhou, J. Perform. Constr. Facil. 30, 1 (2016)

27. L. Y. Ding et al., Autom. Constr. 36 (2013)

28. H. Samarghandi, S. M. M. Tabatabaei, P. Taabayan, A. M. Hashemi, and K. Willoughby, J. Constr. Dev. Ctries. 21 (2016)

29. H. Doloi, A. Sawhney, K. C. Iyer, and S. Rentala, Int. J. Proj. Manag. 30, 4 (2012)

30. A. Kazaz, S. Ulubeyli, and N. A. Tuncbilekli, J. Civ. Eng. Manag. 18, 3 (2012)

31. M. Sambasivan, T. J. Deepak, A. N. Salim, and V. Ponniah, Eng. Constr. Archit. Manag. 24, 2 (2017)

32. A. Shebob, N. Dawood, R. K. Shah, and Q. Xu, Iss Int. J. Manag. Proj. Bus. 19,1 (2012) 